\title{
Constraints to Urban Planning and Management of Secondary Towns in Uganda
}

\author{
Amin Tamale Kiggundu \\ Received: 02022014 / Accepted: 2602 2014 / Published online: 30062014 \\ Cㄱ 2014 Faculty of Geography UGM and The Indonesian Geographers Association
}

\begin{abstract}
Many towns in Uganda are growing at an unprecedented rate. By 2030 more than 50\% of Ugandans will be living in urban centres. This rapid growth of urban centres in Uganda provides for economic opportunities for many urban residents. It also poses various challenges such as urban sprawl, emergence of informal settlements as well as urban poverty. Over $60 \%$ of the urban residents in Uganda live in the informal settlements with no basic services and infrastructure such as piped water, decent housing, good roads, sewerage systems as well as schools and health centres. This paper aims to examine and understand the constraints to urban planning and management of secondary towns in Uganda. Using an eclectic mix of research methods such as face to face interviews targeting key informants, a questionnaire survey as well as observation, the study found that the current modernist planning approach has not achieved its intended goal of promoting orderly urban development and improve service delivery in the secondary towns. The study also revealed that the urban residents are rarely involved in planning. Besides, there is an apparent mismatch between what is taught at the local planning schools and what is required in terms of planning in the secondary towns. To address these intractable urban challenges, it is critical that the current planning education and curriculum are reviewed to produce creative and imaginative planners that can respond more effectively to the community problems, adopt a strategy to promote strategic spatial planning that is more participatory, carry out public awareness campaigns about the need for proper planning of towns and adopt a strategy for promoting innovative funding programmes such as municipal bonds, use of the stock exchange to mobilise the required investable funds, allow the private sector to access institutional funds such as the employee provident fund and promote public-private partnerships.
\end{abstract}

Keywords: Urban planning and management, constraints and secondary towns

Abstrak Banyak kota-kota di Uganda tumbuh pada tingkat yang belum pernah terjadi sebelumnya. Pada tahun 2030 diprediksi lebih dari 50 \% dari Uganda akan tinggal di pusat-pusat perkotaan. Pertumbuhan yang cepat ini pusat-pusat perkotaan di Uganda menyediakan peluang ekonomi bagi banyak penduduk perkotaan. Hal ini juga menimbulkan berbagai tantangan seperti urbanisasi, munculnya permukiman informal serta kemiskinan perkotaan. Lebih dari $60 \%$ dari penduduk perkotaan di Uganda tinggal di permukiman informal tanpa layanan dasar dan infrastruktur seperti air bersih, perumahan yang layak, jalan, sistem pembuangan limbah serta sekolah dan pusat kesehatan. Makalah ini bertujuan untuk mengidentifikasi dan memahami kendala untuk perencanaan dan pengelolaan kota-kota sekunder di perkotaan Uganda. metode penelitian ini menggunakan metode eklektik campuran seperti wawancara langsung dengan menargetkan informan kunci, survei menggunakan kuesioner serta observasi, studi ini menunjukan bahwa saat ini pendekatan perencanaan modernis belum mencapai tujuan yang dimaksudkan untuk mempromosikan pembangunan perkotaan tertib dan meningkatkan pelayanan di kota-kota sekunder. Penelitian ini juga mengungkapkan bahwa penduduk kota jarang terlibat dalam perencanaan. Selain itu, ada ketidakcocokan yang jelas antara apa yang diajarkan di sekolah-sekolah perencanaan lokal dan apa yang dibutuhkan dalam hal perencanaan di kota-kota sekunder. Untuk mengatasi tantangan ini, sangat penting bahwa pendidikan perencanaan saat ini dan kurikulum yang terakhir untuk menghasilkan perencana yang kreatif dan imajinatif yang dapat merespon lebih efektif terhadap masalah-masalah masyarakat, mengadopsi strategi untuk mempromosikan perencanaan tata ruang strategis yang lebih partisipatif, melaksanakan kampanye kesadaran masyarakat tentang perlunya perencanaan yang tepat dari kota-kota dan mengadopsi strategi untuk mempromosikan program-program pendanaan inovatif seperti obligasi daerah, penggunaan bursa efek untuk memobilisasi dana yang dapat diinvestasikan untuk kepentingan pembangunan, memungkinkan sektor swasta untuk mengakses dana institusional seperti dana kesejahteraan karyawan dan mempromosikan kemitraan publik-swasta .

Kata kunci: Perencanaan dan manajemen perkotaan, kendala pada kota-kota sekunder.

\section{Introduction}

Like most countries in Sub Saharan Africa, Uganda is experiencing rapid urbanisation. About $19 \%$ of the Uganda's population lives in urban areas and it is projected that by 2050 half of Uganda's population will be living in urban centres. Uganda's annual urban growth rate of

\footnotetext{
A. Tamale Kiggundu

Department of Architecture and Physical Planning, Makerere University

Email:akiggundu@Cedat.mak.ac.ug
}

$5.1 \%$ is one of the highest in Africa. Due to institutional fragility as well as the failure to implement existing physical development plans however, most urban residents in Uganda live in informal settlements. (Figure 1)

Aside from a few municipalities like Jinja and Mbale that benefited from the initial colonial town development programme, most secondary towns in Uganda have been growing and expanding without a clear physical development strategy. Development in most 


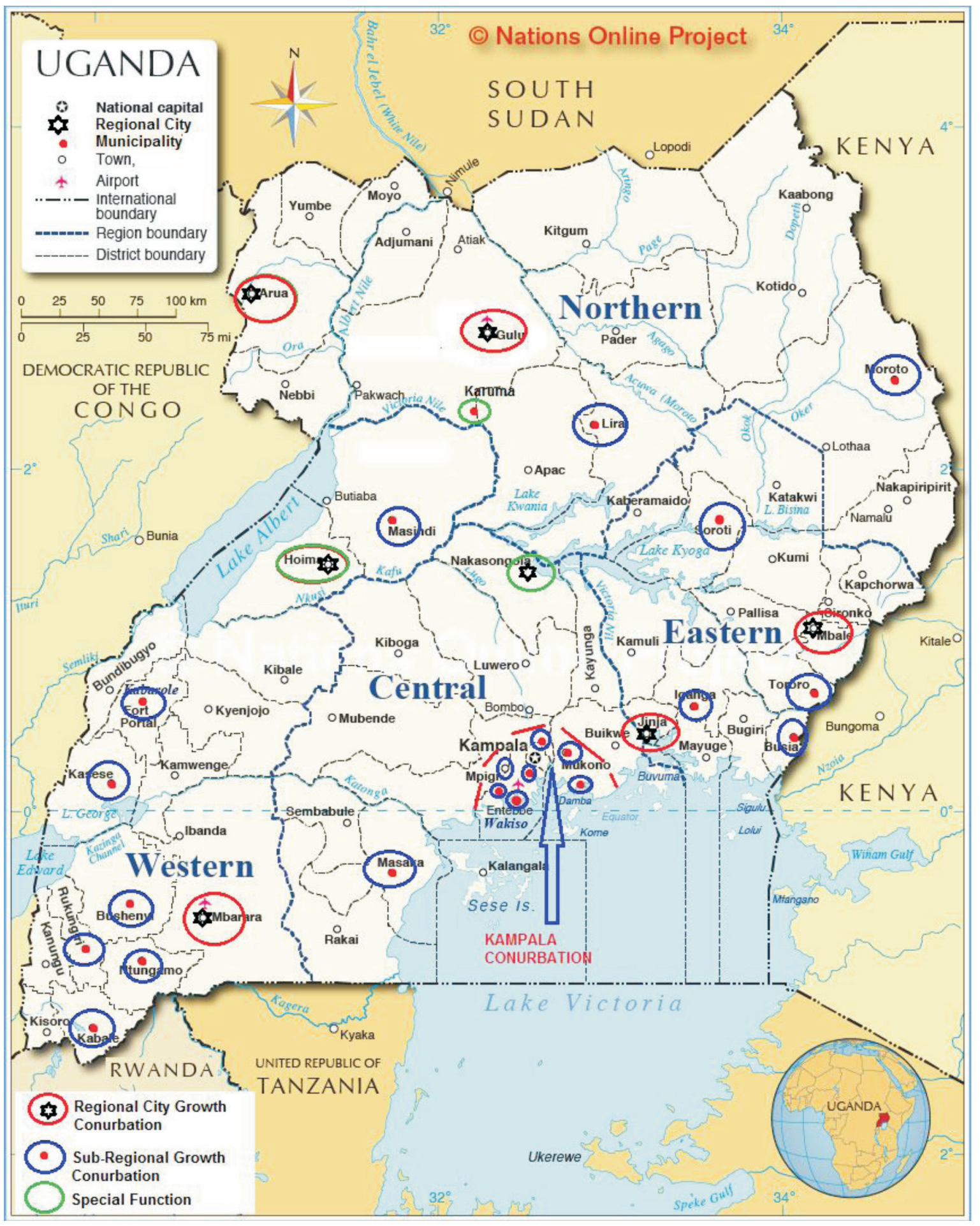

Figure 1. Map of Uganda (Source: Ministry of Lands, Housing and Urban Development)

secondary. In the absence of a coherent land compensation policy as well as the numerous weaknesses and constraints associated with existing municipal funding systems such as the National Road Fund (NRF) as well as the conditional grants from the central government, secondary towns with small local revenue base continues to grapple with the challenge of funding basic infrastructure such as roads, piped water and schools.
This study aims to understand and examine the constraints to physical planning as well as the management of secondary towns in Uganda. Research results are presented and discussed under various sections. Section one focuses on the background of the study. This is followed by a section on the objectives of the study. Next to this is the research methodology, followed by the scope of the study, key features of the secondary towns, cur- 
Table 1. Key features of the secondary towns in Uganda

\begin{tabular}{clrrrrr}
\hline No & Item & Mbale & Arua & Mbarara & Jinja & Kabale \\
\hline 1 & Size of town (Sq Km) & 24.35 & 10 & 51.5 & 88 & 28 \\
2 & Total population & 86,642 & 53,600 & 102,926 & 132,150 & 54,407 \\
3 & Annual population growth rate \% & 4 & 4 & 5.1 & 3.2 \\
4 & Total population of slum dwellers \% & 45 & 47 & 61 & 16 \\
5 & Number Of slum settlements & 6 & 6 & 11 & 8 \\
6 & Area covered by slums (Acres) & 335 & 452 & 3,400 & 695 \\
\hline
\end{tabular}

Source: Ministry of Lands, Housing and Urban Development [2009] ; Actogether [2010]

rent planning strategy in Uganda, urban management in Uganda, challenges and constraints to planning, best practices, conclusion and policy recommendations.

\section{The Methods}

The overall objective of this study is to examine the constraints to urban planning and management in secondary towns in Uganda. Specifically, the study aims to: (i) examine the current urban planning strategies and management styles in secondary towns in Uganda, (ii) examine the effectiveness of the current planning and management systems in promoting orderly urban development and providing basic infrastructure, and (iii) identify and examine the best practices from international experiences that are transferable to Uganda for better planning and management of secondary towns.

The study applied an eclectic mix of research methods. Specifically, the researchers used observation as well as face to face interviews to collect the required information. Face to face interviews targeting key informants such as representatives of Slum Dwellers International (SDI), representatives of Actogether, municipal officials, members of the municipal urban forum and local community leaders were carried out in the five TSUPU project towns of Mbale, Jinja, Arua, Mbarara and Kabale. An interview schedule was also used to carry out face to face interviews.

The selected key informants and stakeholders were targeted because: (a) they were knowledgeable about the issues being investigated in the five secondary towns; (b) there was need to assess the extent to which they areinvolved in promoting physical planning and good urban governance; (c) some of them are directly involved in the implementation of government programmes. Extensive review of the existing literature on slum development in Uganda and other countries was also carried out by the researchers. Slum profile reports prepared by Actogether and Slum Dwellers $(S D I)$ in the secondary towns also reviewed. Best practices were identified for adoption in Uganda.

The study focused on slum settlements in secondary towns of Mbarara, Arua, Kabale, Jinja and Mbale. It also examined the constraints to physical planning and management in the five TSUPU project towns. TSUPU means the Secondary Cities Support Programme for Transforming Settlements for the Urban Poor in Uganda. The TSUPU proj- ect is funded by the World Bank and Cities Alliance. The five TSUPU project towns were selected taking into account regional balance, size and growth rate as well as an equitable spread of resources. Researchers also identified and explicated the best practices in physical planning and urban management that could be adopted in the five secondary towns in Uganda.

\section{Result and Discussion}

Among the key features and characteristics of the TSUPU secondary towns is the high urban population growth rate. On average, the population in secondary towns has been growing at $4 \%$ each year. Besides, annual population growth rates in the secondary towns are also higher than the national average, which is estimated at $3.2 \%$. Widely recognised also is the development and expansion of informal settlements. A study carried out by a local Nongovernmental Organisation (NGO), Actogether, in five TSUPU project towns in 2010 found that Mbale town had 6 slum settlements, Arua 6, Mbarara 11 , Jinja 8 and Kabale 12. The area covered by these settlements has also increased in the recent years to 335 acres in Mbale, 452 acres in Arua, 3400 acres in Mbarara, 695 acres in Jinja and 751 acres in Kabale.

Slum dwellers constitute about $45 \%$ of the urban population in Mbale, $47 \%$ in Arua, 61\% in Mbarara, $16 \%$ in Jinja and $16 \%$ in Kabale (Table 1). Slum settlements in secondary towns are also characterised by poor quality and inadequate housing infrastructure. Most housing units in slum settlements are built using transient materials such as mud and pole. According to the 2002 Census, about 59\% of dwelling units in urban areas were permanent compared to $10 \%$ in rural area. Also $66 \%$ of the houses built in Uganda were roofed using iron sheets [UBOs, 2013].

Most slum settlements are inaccessible because of poorly planned transport infrastructure. Due to plot sub-division as well as the lack of a clear land compensation policy, the provision of centrally planned services such as roads, piped water and garbage collection in most towns is virtually impossible. Access to clean water is also another big problem in part because most towns lack the required financial resources to provide piped water and to protect key springs as well as wells.

Poor management of human waste is also an issue that has not been adequately addressed. Most 
secondary towns lack lagoons for managing human waste and cases of water born diseases such as Cholera and Diarrhoea have been on the increase. Defecating into polythene bags, then disposing the bag haphazardly, is common in many towns. Sometimes the bags, known as "flying toilets", are simply flung into drainage channels, garbage skips and rivers.

Affected by economic stagnation and high rate of unemployment, informal settlements often accommodate the urban poor and people with very low education and insufficient skills. Most slum dwellers in the secondary towns are self-employed people, carrying out street vending and operating Boda Boda (commercial motorcycles) transport business.

Modernist planning is the most dominant planning system used in Uganda. The system is based on developing master plans as well as detailed plans. Modernist planning was first introduced in Uganda and other African countries by the British colonialists. The system emerged in the latter part of the 19th century, largely in response to rapidly growing, chaotic and polluted cities in Western Europe, brought about by the Industrial Revolution [UN-Habitat, 2009].

Modernist planning was introduced in the United Kingdom $(U K)$ and America as a state function in part because of the preponderance and influence of the Keynesian economic ideas that favoured and promoted state intervention in the economy [UN-Habitat, 2009]. The central ideology of master planning is zoning. Zoning aims to separate incompatible land uses (such as industrial development, markets, recreational facilities and housing) and promote orderly urban development.

Under the modernist planning system, planning is viewed as a technical activity to be carried out by trained experts with little involvement of the urban residents. Modernist planning tends to be comprehensive and over ambitious, with broad objectives intended to address all the urban challenges, something that has undermined its ability to transform urban settlements and eradicate slum settlements in many developing country towns and cities.

One of the key features of the current planning system in Uganda is the continued dependence of international consultants and experts who are engaged to develop Master Plans. International experts have also been engaged to fill the local skill gap in planning and management of urban centres. Foreign experts are often preferred because of their vast experience and wide knowledge on planning matters. For the donor funded projects, it is also a common practice to treat foreign experts as a key condition for extending financial assistance.

With the recent introduction of urban and regional planning as a degree programme at Makerere University however, many Ugandans have been able to acquire the necessary skills in planning. Some of these planners have also teamed up with foreign planning firms such as Rome Consult from Israel to undertake planning work in various local towns such as Kampala.
Due to the lack of a coherent local funding policy for physical planning activities and programmes, international donor agencies have emerged as a key source of funding. Money to fund physical planning projects has mainly come from the World Bank, Cities Alliance and UN-Habitat. UN-Habitat has for example funded projects intended to prepare master plans for towns such as Arua and Gulu.

The World Bank has funded two separate programmes under the Ministry of Local Government; namely, the Local Government Development Programme 2 [2007] and the Local Government Management and Service Delivery Programme, which ended in 2013. Under the two programmes, money was secured from the World Bank to fund the preparation of physical development plans for several towns.

Also worthy of mention is that the World Bank has provided financial resources to fund the Uganda Support to Municipal Infrastructure Development programme (USMID), which is intended to improve infrastructure facilities in various secondary towns. The programme is being implemented by Ministry of Lands, Housing and Urban Development (MoLHUD). Under the same project money has been earmarked for the preparation and development of Master Plans and Detailed Plans of towns such as Moroto and Hoima.

In Uganda as elsewhere in the developing world, planning is still an exercise that is dominated by the government. While the decentralisation policy was largely introduced to bring power nearer to the people and to foster citizen participation in the decision making process, planning in most local urban councils is still undertaken with little or no contribution from the local communities and urban residents. Government dominated planning is also a critical characteristic of command economies that favoured centralised planning and government intervention in the economy to provide key services and basic infrastructure such as housing, roads, hospitals and schools [Phan, 2002].

Under this section,various urban governance and management issues are discussed and examined. Critical among them are:

The 1995 Constitution ushered in a new era of decentralization that led to eventual ratification of local governments. Hence, the district became the local government below which all lower local governments and other administrative units drew power, roles, responsibilities and functions. Having judicial, political, administrative and legislative power, they became corporate bodies that had perpetual succession and with powers to sue and be sued.

Among the objectives and aims of the decentralization policy are: (a) To transfer real power from central government to lower level local government units; (b) To ensure that decentralization became the guiding principle to all levels of government for purposes of promoting democratic citizen participation in decision making; (c) To facilitate good governance; and (d) En- 
sure that effective administrative control of services to the level of bringing them closer to the people, for accountability, a sense of ownership and implementation.

Under the Local Government Act 1997 CAP 243, the planning function was decentralised to the urban local councils and districts. Most districts and urban councils have now employed physical planners. However, the staff structure in both municipal and town councils provides for only one position of a physical planner.

Physical planners are also treated as part of Engineering and Works Department. It is only under the Kampala Capital City Authority Act [2010] that a fully fledged Directorate for Physical Planning with several planners was established to control and guide physical developments in the city. Schedule 2 of the Local Government Act 1997 identifies the responsibilities of the different levels of governance in infrastructure development and maintenance. Also under the same Act the Central Government is mainly responsible for the formulation of different sector policies. The urban councils including cities, town councils and municipalities are supposed to provide decentralised social services and basic infrastructure. Urban local councils are also charged with road maintenance, provision of utilities such as water and electricity as well as social services such as schools and hospitals.

One of the key objectives of the decentralisation policy is to promote citizen participation in the decision making process. However, the idea of engaging the urban residents in undertaking physical planning activities in many towns in Uganda is rather new. Rarely are the various stakeholders engaged and encouraged to participate in development of physical development plans.

While there are guidelines made by the Ministry of Local Government to be used by the local governments to engage the public in developing economic development plans, the urban sector in Uganda lack a clear strategy to foster public participation in the development of physical development plans for the towns.

Even where consultants have been engaged by the government to undertake a physical planning exercise with clear terms of reference sometime requiring them to consult the urban residents in drawing up the physical development plans, the levels of participation among key stakeholders have been rather low. A study conducted by Jjukko [2013] in Masaka municipal council revealed that only $28 \%$ of the urban residents were consulted, $41 \%$ not sure and $31 \%$ indicated that they were not consulted at all during the preparation of a physical development plan for the town.

In absence of clear guidelines for engaging the urban residents and key stakeholders in carrying out physical planning, development in several local towns has continued to occur chaotically and without control.

In many local urban councils land has been allocated and developed without taking into account the existing development control requirements such as the physical development plans. Such land is often in the hands of the district land boards, which are mandated under the 1995 Constitution to manage all the land owned by the government. In Mbale town, according to the interviews conducted with key informants, land which was originally planned as a public park was subdivided into several plots and allocated to developers. This happened after the District Land Board had given a green light.

Planning laws are critical in determining how urban growth is managed and regulated. In Uganda, most planning laws are a replica of the British Town and Country Planning Law of 1947. Uganda's Town and Country Planning Law of 1964 was also formulated basing on the British colonial planning laws implemented in Africa and the Caribbean. Among the physical planning laws used by urban councils in Uganda today are:

The Local Government Act 1997 Cap 243: The Local Government Act was introduced in 1997 with the aim of decentralising power from the centre to lower levels of government such as the districts and urban councils. The Act also empowers the Minister of Local Government to create and elevate the status of urban centres in Uganda. The creation and elevation of urban centres in Uganda is largely based on the population size. According the Act, a town council should have a minimum population of 25,000 people, municipality 100,000 and a city 500,000. For the newly created districts, their headquarters automatically become town councils. The Local Government Act however is blamed for treating urban councils and districts as regions with the same needs and requirements.

National Physical Planning Act 2010: The national physical planning Act of 2010 replaced the Town and Country Planning Act of 1964, which was formulated basing on the 1947 British Town and Country Planning Act. The new Act declares the entire country a planning area. It also establishes physical planning committees at districts, town councils and sub-counties. The national physical planning act creates the National Physical Planning Board (NPPB), with the mandate to regulate physical developments in the country. The Board also approves physical development plans for various urban councils in Uganda.

The Condominium Law 2001: The Condominium Property Act of 2001 was introduced to facilitate development, ownership and occupation of flats and sectional properties. The Act was also intended to promote high density housing to meet the increasing housing needs in the urban centres. The move towards high density housing was also necessitated by the surge in urban population as well as the scarcity of land in the major towns.

Kampala Capital City Authority Act: The Kampala Capital City Authority (KCCA) Act was introduced in 2010 as part of the new strategy to restructure the city and introduce a new management style. The Act led to the replacement of Kampala City Council (KCC) by Kampala Capital City Authority. On the administrative side, the Act introduced the positions of the Executive Director and the Lord Mayor. The Lord Mayor is an elected city 
leader while the Executive Director is appointed by the President with recommendation by the Public Service Commission. Besides, the Act provides for the establishment of the Kampala Metropolitan Physical Planning Authority (KMPPA) an institution that is mandated to regulate physical developments in Kampala and surrounding districts of Wakiso, Mpigi and Mukono.

National Physical Planning Guidelines and Standards 2011: The national physical planning guidelines and standards forms the criteria for determining the scale, location and site requirements of various land uses and facilities. The planning standards affect the location of scarce land and financial resources. They are also supposed to be applied with flexibility. The standards are applied in four aspects: forward planning (equitable basis for allocating scarce land resources), development control, plan implementation as well as raising quality of life.

A widely shared view is that planning is a broad exercise and activity, intended to address all the issues and challenges faced by urban centres. In many developing country towns and cities however, planning has failed to bring about the desired goals. This is partly due to the nonplanning factors such as the lack of the necessary institutional capacity as well as inadequate financial resources.

The new thinking however is that planning has to be strategic and selective. Strategic planning is based on identifying a few priorities and critical areas that could spur future development in a town. Towns also need to have visions and action plans intended to achieve a long term development objective. Above all, the urban residents should be given the opportunity to participate in the decision making process and determine the destiny of their town.

While the forces impacting upon the growth and development or towns and cities have significantly changed, in Uganda, urban planning and management systems have virtually remained the same. New urban planning and management strategies are thus required to addresses emerging challenges and critical issues such as citizen participation in the decision making process, rural urban-migration, climate change, globalization, sustainable urban development, disaster management, oil depletion as well as food security.

Zoning, which is a key characteristic of master planning and modernist planning approach is popular and dominant in Uganda. However, zoning has been blamed for promoting a mono-centric urban structure especially in big towns like Kampala. Zoning has also separated settlement areas from the people's work places, something that has increased travel distances and the need for travel in many towns. The separation of settlements from work places has also caused traffic jam in many towns.

Most slum dwellers in secondary towns live without any form of secure tenure and under constant threat of eviction, something that affects their ability to access credit and constrains their motivation to improve their homes and neighbourhoods. The challenge is to develop new innovative tenure types, which are affordable to the urban poor. Slum settlements that are not titled challenge the existing land registration and cadastral approaches. There is need therefore to think beyond conventional titling approaches that have perpetuated slum development in many towns.

As mentioned before, the 1995 Constitution vested land in the citizens of Uganda who privately own it under various land tenure systems and categories such as Mailo, Leasehold, Freehold and Customary. Major investors including the government often face challenges and problems in securing the required land for implementing their projects. Also important is the issue of plot subdivision and land fragmentation in various towns.

Rarely are the national physical planning guidelines and standards followed when issuing land titles in areas where plot subdivision is common and popular among the urban residents. The smallest plot size, according to these guidelines is 11 decimals (50 $\mathrm{x} 100$ feet). Plot subdivision is a serious land management problem in many towns in Uganda because it makes the provision of centrally planned services such as roads, piped water and sewerage systems more difficult and impossible to provide.

Concerns have also been raised about the land allocations made the district land boards without taking into account the existing land use plans. District land boards were established under the 1995 constitution to manage land that is owned by government in the districts and urban councils.

Some of the existing urban laws and development control legislations have become obsolete and overtaken by events. Key sections of these laws cannot be effectively applied to regulate physical developments in the secondary towns. Penalties provided under the Public Health Act of 1964 for erecting illegal structures are for example not severe enough to discourage the urban residents from breaking the law.

Under the Local Government Act of 1997 both urban councils and rural local governments (especially districts) are treated as regions with the same needs and requirements. This is very unfair. Urban areas tend have more problems, more people and therefore different needs. Virtually all the existing urban laws do not recognise the existence of informal settlements and yet over $60 \%$ of Uganda's urban population lives in slum settlements.

Most urban residents are self-employed especially as street food vendors, retail shop owners and informal restaurant owners. The informal sector also constitutes a large percentage of the urban economy. While the central government is mandated under the Local Government Act CAP 243 to establish and elevate the status of urban centres, most towns in Uganda have either been established by the private real estate developers such as Jomayi or the local people themselves.

Planning laws that promotes zoning in cities and towns where development is ahead of planning have miserably failed to achieve their intended 
goal of promoting orderly urban development and improving social service delivery. Planning has also been ineffective in part because of the non-planning factors such as inadequate funding, poor enforcement, failure to recognise local urban value systems in planning as well as the land tenure systems. These factors are rarely taken into consideration while formulating urban laws and preparing master plans.

Among the key constraints to citizen participation in the preparation of physical development plans and detailed plans in Uganda are illiteracy and poverty [Jjuko, 2013; Matovu, 2006]. People who are preoccupied with basic survival needs or traumatised by certain diseases will hardly find it worthwhile to participate in community based activities [Jjuko, 2013]. Furthermore, the high incidence of poverty in Entebbe municipality impacted negatively on civic participation in the decision making process in general and in the budgeting process in particular. Citizens tend to focus more on activities which will earn them an income on a daily basis than on activities which will benefit them in medium and long term period [Kudishora, 2006; Matovu, 2006].

Odogkara [1996] argue that Ugandans are poor and a day at a seminar to discuss environmental problems means a day unpaid. If people have to choose between tending to their life and going to a meeting, they will definitely choose to tend to their life [Jjukko,
2013]. Results from a questionnaire survey carried out in Mbarara, Arua, Jinja, Kabale and Mbale town show that the majority of respondents $(65 \%$ of the household heads/urban residents surveyed) are not aware of the existence of the physical development plans and have never got chance to know their contents.

Citizen participation in planning has also been affected by the lack of a clear strategy and approach to promote participatory planning. New feasible strategies are therefore required to encourage the urban residents to participate in planning. In addition, the urban residents need to be encouraged to participate in the implementation of physical development plans which are still shelved in many towns across the country.

Political interference has been identified as one of the challenges faced in promoting physical planning and orderly urban development in Uganda. Local politicians often interfere to safeguard their interests and gain support among the urban residents. Policies formulated to streamline the operation of Boda Boda transport (commercial motor cycles) in the major towns have also failed in part because of the lack of support among politicians and also the thinking that they are anti-poor.

Commercial motor cycle operators often operate from every area in town, without designated stages to pick and disembark passengers. The laws intended to promote the use of helmets among Boda Boda op-

Table 2. Financial performance and allocations for physical planning in five municipalities

\begin{tabular}{llrrrrr}
\hline No & \multicolumn{1}{c}{ Category } & Mbarara & Jinja & Arua & Kabale & Mbale \\
\hline 1 & $\begin{array}{l}\text { Total annual budget in Billion } \\
\text { Shillings }\end{array}$ & 8 & 9.1 & 5 & 7.2 & 8.2 \\
2 & $\begin{array}{l}\text { Local Revenue as \% of the } \\
\text { budget }\end{array}$ & 25 & 35 & 14 & 18 & 17 \\
3 & $\begin{array}{l}\text { Allocations for physical planning } \\
\text { programmes 2013/14 }\end{array}$ & Shs 35 Million & Shs11 Million & Shs9million & Shs8million & $\begin{array}{r}\text { No alloca- } \\
\text { tion }\end{array}$ \\
4 & 67 & 64 & 66 & 62 & 64 \\
\hline Source: Ministry of Local Government & & & & &
\end{tabular}

Table 3.Urban Grants From the Central Government 2000 - 2009

\begin{tabular}{|c|c|c|c|c|c|}
\hline No & FY & $\begin{array}{r}\text { Total Grants to all } \\
\text { Urban Local Govern- } \\
\text { ments in Uganda in } \\
\text { Shs Billion }\end{array}$ & $\begin{array}{r}\text { Unconditional Grants } \\
\text { from the Central } \\
\text { Government to Urban } \\
\text { Local Governments, } \\
\text { Shs Billion }\end{array}$ & $\begin{array}{r}\text { \% Share of Uncondi- } \\
\text { tional Grants to Total } \\
\text { Grants for all Local } \\
\text { Governments }\end{array}$ & $\begin{array}{r}\text { Urban Grants as \% of } \\
\text { all Local Government } \\
\text { Grants in Uganda }\end{array}$ \\
\hline 1 & $2000 / 01$ & 5.2 & 4.2 & 78 & 1 \\
\hline 2 & $2001 / 02$ & 5.9 & 4.7 & 78 & 0.9 \\
\hline 3 & $2002 / 03$ & 11.2 & 4.9 & 43 & 1.7 \\
\hline 4 & $2003 / 04$ & 10.4 & 5.4 & 52 & 1.4 \\
\hline 5 & $2004 / 05$ & 11.9 & 5.9 & 49 & 1.5 \\
\hline 6 & $2005 / 06$ & 24.4 & 18.4 & 75 & 2.8 \\
\hline 7 & $2006 / 07$ & 22.9 & 17.1 & 75 & 2.4 \\
\hline 8 & $2007 / 08$ & 33.6 & 25.2 & 75 & 3.2 \\
\hline 9 & $2008 / 09$ & 40 & 26.2 & 65 & 3.4 \\
\hline
\end{tabular}


erators have also not been enforced. Powerful politicians and business people who are linked to high government offices often build in wetlands and other fragile environments, something that is inconsistent with the existing physical development plans.

Due to inadequate funding most towns are unable to implement their physical development plans. Physical planners in most towns are also not facilitated to do their work-----that is, they lack offices, have no computers and have no vehicles. Even where money has been allocated to fund physical planning activities, the amount involved is usually too small to make an impact.

Face to face interviews carried out with the municipal officials in the five secondary towns show that in Mbarara about Shs 35 million was allocated for physical planning activities during the 2013/4 financial year. It was also established that Mbale municipal council had no specific budget for physical planning. Kabale had Shs 8million and Arua had Shs 9 million (see Table 2).

To note also is that the grants sent to various towns each year by the central government are based on population figures extracted from the census reports prepared by Uganda Bureau of Statistics (UBos) every after ten years. Ten years is obviously a long period of time and many changes take place before another census is organised. This very reason explains why the urban sector is still underfunded in Uganda.

Due to several competing development priorities, government is often unable to provide adequate funding for all sectors. The challenge also is that urban councils in Uganda heavily depend on the central government funding and have failed to adopt other funding strategies such as public private partnerships, access to institutional funds such as the National Social Security Fund (NSSF), use of the municipal bonds and mobilisation of the investable funds on the stock exchange. These strategies have been used in both Singapore and Malaysia to fund infrastructure projects such as new toll highways, rail systems and social housing

The current staff structures in most local towns are not fully filled. On average urban councils only have about $60 \%$ of the required personnel. In addition, staff structures for urban councils only provide for one physical planner who is affiliated to the engineering and works department. There is a growing realisation and recognition however that towns and cities requires a separate fully fledged department to handle physical planning issues. Under the Kampala Capital City Authority (KCCA) a fully fledged physical planning department was established. Several physical planners were also recruited to promote physical planning and orderly urban development in Kampala.

The reason why KCCA is able to recruit more than one physical planner is that its annual budgetary allocations are far bigger than what most urban councils receive each financial year from the central government. Besides, most of the grants received by urban councils from the central government are conditional grants meant to finance specific projects within these towns and not be used to recruit new staff and pay their salaries.

The lack of accurate data and information is one of the key constraints to physical planning in various towns in Uganda. Data extracted from the national census reports prepared by the National Bureau of Statistics (UBos) are often outdated. National censuses are normally organised every after ten years. Due to rapid urban growth, many negative changes have occurred without the required policy responses and interventions. Policy interventions made by the urban authorities are sometimes ineffective and irrelevant.

Most existing urban laws and legislations are not enforced due to institutional fragility. Besides, existing staff structures do not provide for the recruitment of enforcement officers. Without a clear enforcement strategy for the existing urban laws, it is impossible to promote orderly urban development. As part of the new strategy to enforce the existing urban laws, it is critical that the urban governance structures are strengthened and a new fully fledged enforcement department is established.

The provision of urban infrastructure is still treated as different element of the overall urban development policy and planning. Responsibilities are still divided between different public agencies such as Uganda National Road Authority (UNRA) and National Water and Sewerage Corporation (NW $\mho S C)$.

As a result, the interdependent aspects of urban development are not systematically planned in a coordinated and integrated way, but rather treated as independent from each other with no coordinated guidance. This has resulted in piecemeal and poorly coordinated urban development that does not adequately serve the needs of those living and working in urban areas.

Due to the lack of a clear coordination mechanism between physical planning and urban investment policy, it is hard to provide appropriate urban infrastructure in residential, commercial, and industrial parts of a major town in Uganda.

There is an apparent mismatch between what is taught at local planning schools and what is required in terms on planning in various towns in Uganda. Training in local planning schools is still based on Western planning models and concepts. Over 60\% of the urban residents in Uganda live in slum settlements and yet informal settlements are treated as illegal under the existing urban laws and regulations. Local planning schools have also failed to produce planners who are imaginative, creative and able to respond more effectively to various intrac table problems faced by the urban sector such as the proliferation of slum settlements. The pervasiveness of the informal settlements is also a signthat the planning curriculum has not worked. New core courses on the informal settlements are therefore needed.

The urban authorities in Uganda are faced with the challenge of poor public attitude and perception towards 
physical planning. Developers often build in the road reserves and many structures are erected without approved building plans. The scarcity of land in major towns has also forced many poor urban residents to settle in fragile urban environments such as wetlands and swamps.

Poor public attitude and perception towards planning is also manifested by the failure to address the burgeoning challenge of poor solid waste management in various towns. Garbage is often thrown everywhere in towns including drainage systems that drain storm water off the roads. The failure to promote participatory planning in various towns has also meant that the urban residents remain uninterested in planning programmes.

An important lesson from the modernist planning system is the danger of transplanting planning systems and approaches from one context to another, given the highly varied nature of urban societies across the globe. The purpose of presenting the approaches below therefore is not to suggest models or solutions that can be treated as 'dogmas' but rather to provide innovative strategies that have emerged from international experiences in promoting urban planning. These strategies can be considered after examining the local urban conditions, value systems as well as institutional capacity.

Strategic spatial planning has been adopted in many role model towns and cities across the globe as a strategy to improve the competitiveness of towns and address obstinate challenges faced in promoting modernist planning systems. Strategic planning is also more participatory, allowing the urban residents and communities to shape the destiny of their town.

Various stakeholders are also given chance to participate in developing a common vision for their town as well as to identify key development priorities. Strategic planning is a bottom-up planning system as opposed to a top-bottom approach. Strategic planning is further characterised by the emergence of new urbanism. New urbanism is manifested in form of compact cities as well as mixed use development [UN-Habitat, 2009].

Strategic plans do not address every part of the city but simply focus on only those aspects or areas that are important to overall objectives of the plan. This means that a few sectors where the town has a comparative advantage are identified and promoted to stimulate economic growth and development.

Among large role model cities that have adopted strategic spatial planning is Barcelona in Spain, where a city-wide strategic plan promoted a compact urban form and provided a framework for a set of local urban projects. Curitiba city in Brazil is also cited as another success story. Through strategic planning high density corridors were established to promote public transport and sustainable urban development According to UN-habitat [2009] strategic spatial planning may fail to succeed in many developing country towns and cities because of the weak institutional capacity as well as the lack of adequate financial resources to implement plans that have been prepared.
Identified also as one of the innovative approaches to planning is the City Development Strategy (CDS). A City Development Strategy (CDS) is nothing but a long term action plan developed by various stakeholders with the aim of achieving a common vision. CDS also aims to establish competitive and livable towns. $C D S$ represents a new approach towards planning and is more participatory than modernist planning.

City Development Strategies (CDS) have been widely promoted by UN-Habitat, Cities Alliance as well as the World Bank. In Uganda, a CDS project funded by UN-Habitat was implemented in both Entebbe and Jinja municipalities. Among the key challenges faced in implementing the city development strategy in both was the failure by the Ministry of Local Government to adopt it as a more superior planning approach for the urban councils than the master plans and the five year development plans. In both Jinja and Entebbe, city development strategies were implemented as a mere project and not a broad policy framework for improving spatial planning and promoting urban sustainability. Implementation of city development strategies in both towns required institutional reform as well as a different urban management style, something the initiators of the programme never considered to be important. Community-based planning studios have been promoted as a new strategy to reform the planning curriculum and produce planners that are imaginative and able to respond more effectively to community problems. Community based studios also aim to make planning become more participatory by engaging various stakeholders such as the local communities, slum dwellers, the private sector, policymakers, as well as civil society organisations.

Besides, the strategy is intended to provide a deeper understanding of the challenges and problems faced by the urban communities and make proposals that are realistic and able to foster community development as well as curtail the proliferation of slum settlements.

Community-based studios also emerged as a result of the failure of the existing planning approaches to address the burgeoning problem of the expansion of slum settlements in many towns. In Zambia,

Municipal urban forum is a new urban management concept and strategy that aims to improve urban governance and allow various stakeholders to participate in the decision making process. This urban management approach was introduced in Uganda under the TSUPU project that aims to transform settlements for the urban poor (slum settlements) in secondary towns in Uganda. Under the project, the five municipalities of Mbale, Jinja, Arua, Kabale and Mbarara have established municipal urban forums as well as municipal urban forum committees to foster citizen participation in planning and management of towns.

Municipal urban committees are also supposed to identify projects that can be funded under the TSUPU project in the respective towns. There is also a com- 
munity contract committee that monitor the implementation of the various projects identified under the TSUPU programme. Interviews conducted with key informants including municipal officials in various TSUPU project towns show that municipal urban forums are not yet institutionalised and that members of the municipal urban form do not have offices.

\section{Conclusion}

A key conclusion that can be drawn from the foregoing discussion in this paper is that the modernist planning system has failed to achieve its intended goal of promoting orderly urban development as well as improving service delivery in various towns in Uganda. Over $60 \%$ of the urban residents in Uganda live in slum settlements with precarious public services. Also the reason why planning is failing is partly because of

\section{References}

Actogether (2010), Arua Municipality Slum Profile, Actogether, Kampala.

Berrisford, S. (2013), How to make planning law work for Africa? Africa Centre for Cities, University of Cape Town.

Isolo, M.P. (2004), Urban Change in Uganda: the Challenge of Managing Urban Areas in a Global Environment, Paper presented at a Conference, university of Illinos, Chicago, USA, 22nd-24th July 2004.

Jjuuko, E. Y. (2012), 'Adherence to physical planning in the provision of infrastructure----A Case of Masaka Municipality', M.A. Thesis, Makerere University, Kampala, Uganda.

Kudisora, P. (2006), Subnational Experiences of Civic Participation in Policy Making and Budgetary Processes: The Case of Soroti Municipal Council in Uganda, The World Bank.

Matovu, G. (2006), Capacity Building for Participatory Planning and Budgeting in Africa: initiatives and Stratetic Perspectives. Municipal Development Partnership for Eastern and Southern Africa, Paper presented at the pan African Conference of Ministers of Local Government held in Maseru, King dom of Lethoso, 30th August to 1st September 2006.

Mbale Municipal Council (2010), The Charter for the Mbale Municipal Development Forum (MMDF), Mbale Municipal Council, Mbale.

Ministry of Lands, Housing and Urban Development (2013), Draft National Urban Policy, Ministry of the non-planning factors such as inadequate funding, poor urban governance, failure to enforce the existing urban laws, complex land tenure systems as well as urban culture and value systems. Besides, there is a mismatch between what is taught at local planning schools and what is required in terms of planning in various local towns. A further issue has to do with the failure to engage the various stakeholders such as the private sector, civil society organisations, urban communities, slum dwellers, policymakers and planning schools in planning and management of urban centres. To achieve its intended goal, urban planning has to be more strategic, participatory and based on local conditions. Last but not least, there is need to reform the planning curriculum and education so as to produce planners that are creative and able to respond more effectively to the community needs and problems.

Lands, Housing and Urban Development, Kampala.

Ministry of Lands, Housing and Urban Development (2010), Guidelines for the Development of City Development Strategies and Slum Upgrading Strateies, Ministry of Lands, Housing and Urban Development, Kampala.

Ministry of Lands, Housing and Urban Development (2010), The Charter for the Uganda National Urban Forum (UNUF), Ministry of Lands, Housing and Urban Development, Kampala.

Ministry of Lands, Housing and Urban Development (2013), Urban Situation Analysis: Issues Paper, Kampala, Uganda.

Odogkara, O.K. (1996), Community participation in planning for Jinja, Uganda: Model Communities Programme, International Development Research Centre, Kampala.

Phan, S.N. (2002), Urban Challenges to Local Government in the Era of Globalisation, Borneo Review 12 (2): 153-170.

UBoS/Uganda Bureau of Statistics (2013), Uganda National Household Survey 2013/14, UBos, Kampala,.

UN-Habitat (2007), Situation Analysis of Informal Settlements in Kampala---- Kivulu and Kinawataka Parishes, UN-Habitat, Nairobi.

UN-Habitat (2009), Planning Sustainable Cities-----Global Report on Human Settlements, Earthscan, London. 